\title{
Transformation of Solid Waste Management in China: Moving towards Sustainability through Digitalization-Based Circular Economy
}

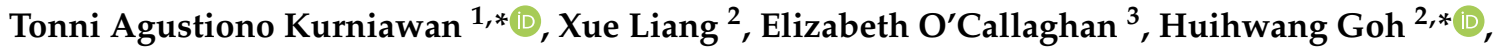 \\ Mohd Hafiz Dzarfan Othman ${ }^{4}$, Ram Avtar ${ }^{5}$ (D) and Tutuk Djoko Kusworo ${ }^{6}$
}

check for

updates

Citation: Kurniawan, T.A.; Liang, X.; O'Callaghan, E.; Goh, H.; Othman, M.H.D.; Avtar, R.; Kusworo, T.D. Transformation of Solid Waste Management in China: Moving towards Sustainability through Digitalization-Based Circular Economy. Sustainability 2022, 14, 2374 https://doi.org/10.3390/su14042374

Academic Editor: Antoni Sánchez

Received: 28 January 2022

Accepted: 16 February 2022

Published: 18 February 2022

Publisher's Note: MDPI stays neutral with regard to jurisdictional claims in published maps and institutional affiliations.

Copyright: (c) 2022 by the authors. Licensee MDPI, Basel, Switzerland. This article is an open access article distributed under the terms and conditions of the Creative Commons Attribution (CC BY) license (https:// creativecommons.org/licenses/by/ $4.0 /)$.
1 College of the Environment and Ecology, Xiamen University, Xiamen 361102, China

2 School of Electrical Engineering, Guangxi University, Nanning 530004, China; 2012401014@st.gxu.edu.cn

3 Department of Chemical Sciences, Bernal Institute, University of Limerick, V94 T9PX Limerick, Ireland; elizabeth.ocallaghan@ul.ie

4 Advanced Membrane Technology Research Centre (AMTEC), School of Chemical and Energy Engineering, Universiti Teknologi Malaysia (UTM), Skudai 81310, Malaysia; hafiz@petroleum.utm.my

5 Faculty of Environmental Earth Science, Hokkaido University, Sapporo 0600808, Japan; ram@ees.hokudai.ac.jp

6 Department of Chemical Engineering, Faculty of Engineering, Diponegoro University, Semarang 50275, Indonesia; tdkusworo@che.undip.ac.id

* Correspondence: tonni@xmu.edu.cn (T.A.K.); hhgoh@gxu.edu.cn (H.G.)

\begin{abstract}
In China, environmental pollution due to municipal solid waste (MSW) over-generation is one of the country's priority concerns. The increasing volume and complexity of the waste poses serious risks to the environment and public health. Currently, the annual growth of MSW generation is estimated to be approximately $8-10 \%$ and will increase to 323 million metric tons (Mt) by 2030. Based on the secondary data collected from a literature survey, this article critically evaluates the recent progress of MSW management (MSWM) in China and offers new insights into the waste sector in the era of Industry 4.0. This helps decision makers in China to plan a smooth transition nationwide to a circular economy (CE) in the waste sector. It is evident that digitalization is a driving force for China to move towards low-carbon development strategies within the framework of CE. Through digitalization, the waste sector has promoted prevention, reduction, reuse, and recycling (3Rs) of waste before waste disposal in landfills. A proper implementation of digitalization-based waste recycling has contributed to an efficient cooperation between the government and private sector, increased job opportunities, and promoted the conservation of resources. It is anticipated that this work not only contributes to the establishment of an integrated MSWM system in China, but also improves local MSWM through digitalization in the framework of a CE.
\end{abstract}

Keywords: circular economy; digitalization; industry 4.0; greenhouse gas (GHG)

\section{Introduction}

Over the past decades, China has undergone a rapid economic development due to urbanization. The country has a large population of 1.4 billion with an increasing gross domestic product (GDP) [1]. Figure 1 shows China's GDP trend from 1969 to 2013. Since the implementation of the open door policy in 1980s, China's economy has developed significantly, with its GDP rising to USD 1,015,986 billion [1]. The pace and scale of China's economic development has been unprecedented globally [2].

Although the country's standard of living has substantially improved and its robust economic growth have significantly contributed to global economic growth, its peaceful rise has encountered major environmental challenges. China has recently been confronted with the over-generation of solid waste. One of the sources of waste originates from demolition 
waste and mining [3-6]. Consequently, environmental pollution has increased in severity and constrained its socio-economic development.

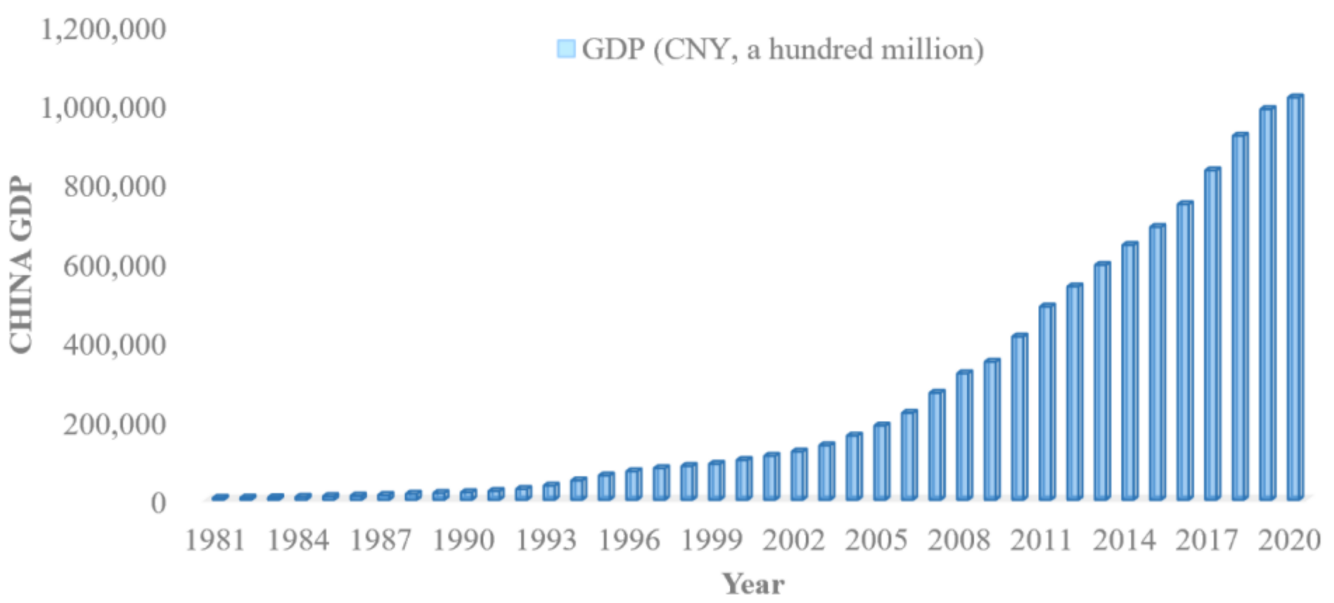

Figure 1. China's GDP trend (1981-2020) [7].

Over $80 \%$ of China's cities consist of organic garbage [7]. In addition, increasing po-pulation growth and urbanization contribute to the over-generation of MSW [8]. The disposal of large amounts of MSW also plagues other developing countries [9].

In 2020, the total annual MSW production reached 235.12 million metric tons (Mt) (Figure 2). The global average annual growth rate of MSW was $8.4 \%$, which is low compared to that of China (10\%) (Figure 3). In 2014, the disposal rate of MSW reached $91.8 \%$, higher than the $66.8 \%$ in 2008 [8]. As MSW generation increases annually, over $25 \%$ of cities have no suitable place for waste disposal, while over $60 \%$ of cities are confronted with the waste [10].

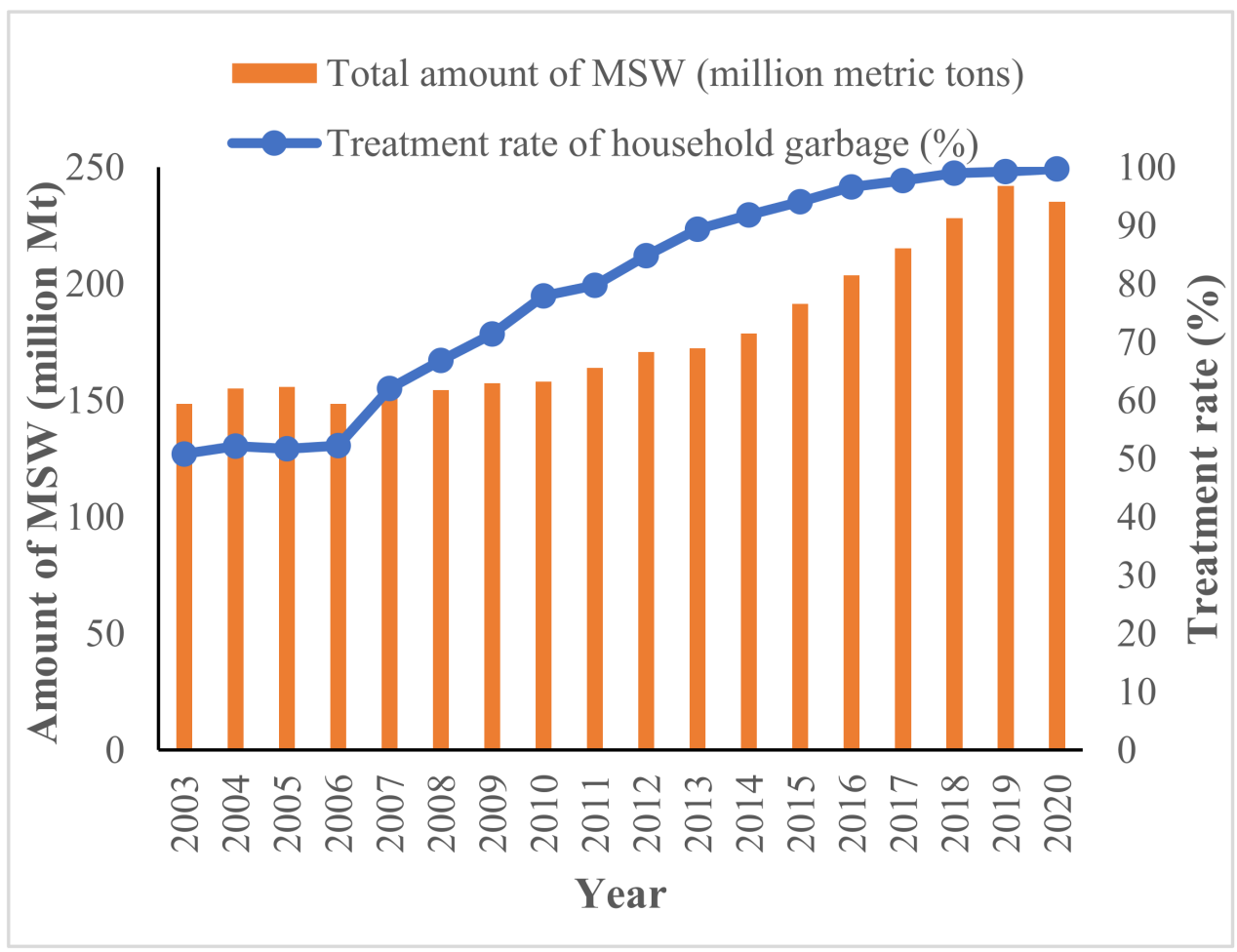

Figure 2. MSW generation and disposal rate from 2003 to 2020 in China [7]. 


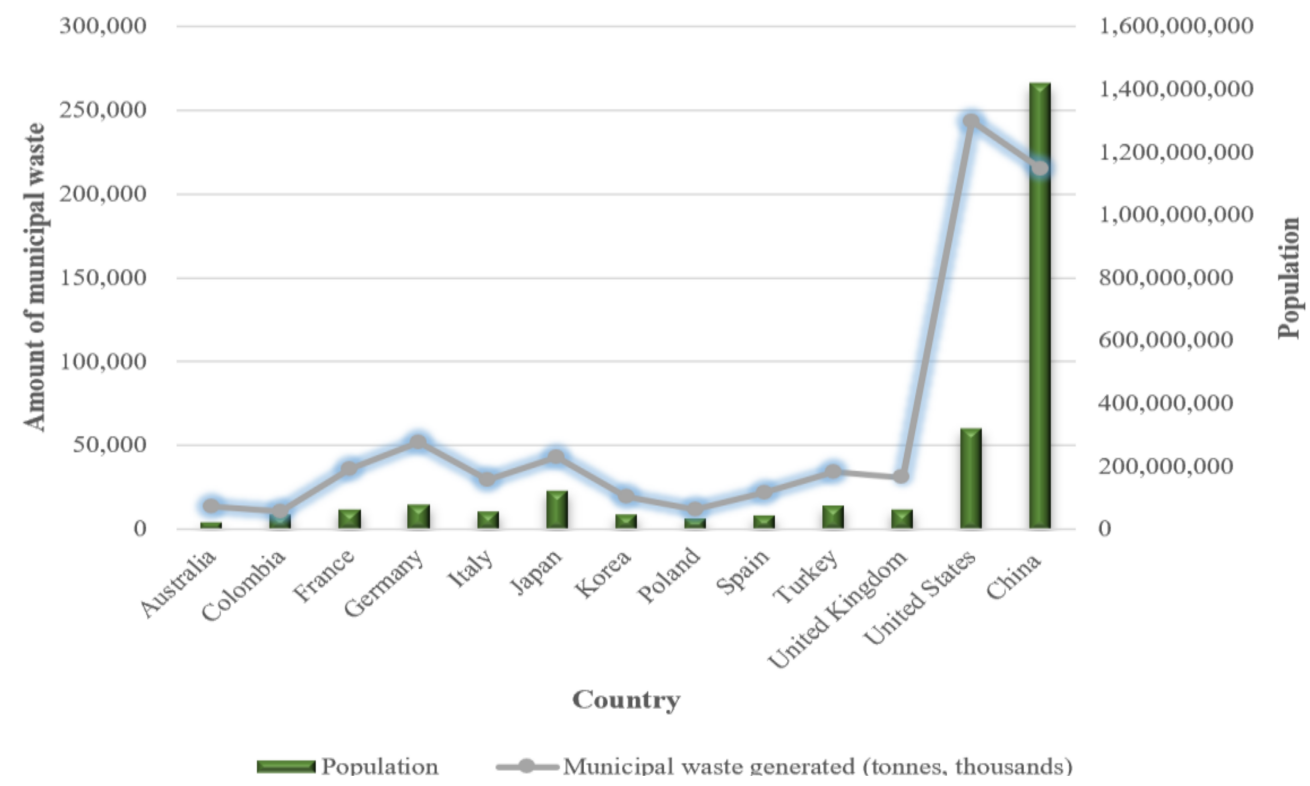

Figure 3. Comparison of MSW growth rate in China and other countries [8].

In China, current challenges include reducing consumption to prevent waste production and increasing recycling rates, as local communities produce much more waste than their counterparts in non-industrial countries [11]. Traditional technological practices are not sufficient to overcome the burden of their waste sustainably. To address this, emerging technologies in the era of Industry 4.0 can provide tools, such as digital solutions, to deal with non-biodegradable waste [12].

In addition, an integrated management system and enforced policy implementation from the government is critical for the success of MSWM [13]. As the main engine for global economic growth, China's role in balancing economic growth and environmental protection is paramount. To ensure that this is to continue consecutively from one gene-ration of leadership to another, forming a sound MSWM policy is one of top priorities in China [14]. However, fiscal policy and its management are complicated because China has encountered multiple challenges in recent years amidst the COVID-19 global pandemic [15].

To deal with the pandemic, greening the waste sector, which follows a CE paradigm, not only contributes to the provision of job opportunities, but also mitigates environmental issues caused by MSW, bringing economic benefits for communities [16]. However, the value of non-biodegradable MSW as a resource is neglected. To add to its value in a $\mathrm{CE}$, China needs a digitalization-based waste recycling program to replace the traditional approach and move towards sustainability in the era of Industry 4.0.

To reflect its novelty in the body of literature, this work systematically provides an overview on the gradual transformation of the country's waste management systems over the past decades as it moves towards sustainability and circularity by applying a digitalization-based CE system. This article also identifies and evaluates the current situation of MSWM in China, the enabling conditions for greening the waste sector, and methods for improving MSWM through digitalization-based waste recycling.

\section{Data Acquisition}

Data were collected from a literature survey of published journal articles in the body of knowledge. Relevant articles were retrieved from the body of knowledge on 01 January 2022 using certain keywords, such as "waste treatment", "Industry 4.0", "China", and "digitalization", and works were subsequently analyzed to understand the gradual transformation of waste management in China from the open door policy in the 1980s to today. 


\section{Current Situation of MSWM in China}

In China, the management of MSW is the responsibility of the central authority, including with regard to collection, transportation, and treatment [17]. However, during the process, solid waste treatment is influenced by economic development, environmental policy, and public environmental awareness [18].

MSW is collected formally by the municipality and/or informally by scavengers [19]. The residential cohort takes the waste to collection points by themselves, while the recyclables are collected by the waste collectors via door-to-door collection systems. The MSW generated from industry is collected by private waste collectors. Recyclable materials are separated and sold as processed materials to factories. Then, private waste collectors transport the waste to refuse transfer stations [20]. Eventually, the waste is disposed of in landfill or incinerated.

Landfilling is the main method for the disposal of MSW in China (Figure 4). However, in remote areas, uncontrolled landfills still exist where waste is disposed of without any control measure. Local landfills still encounter difficulties, such as digestive cells filled with unsorted MSW and high amounts of leachate during rainy seasons. This disposal method causes leachate infiltration into the groundwater, leading to secondary pollution.

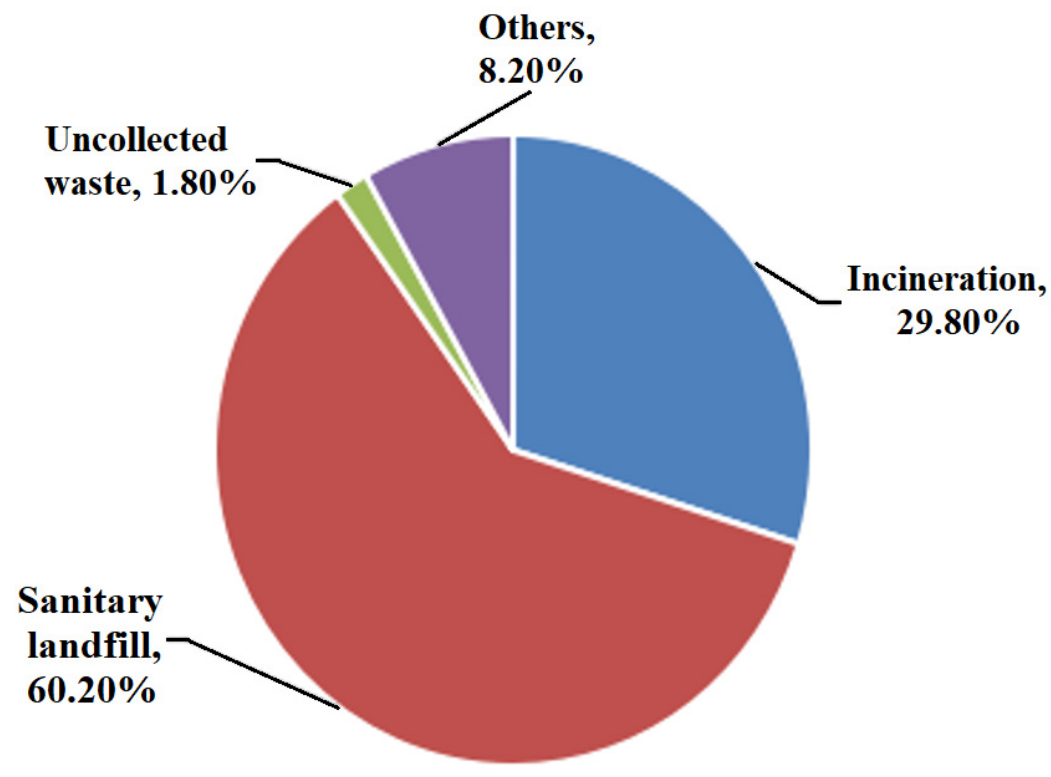

Figure 4. Disposal method for MSW in 2020 [18].

Since 1995, China has introduced incineration plants as an alternative to landfills [21]. The first garbage power plant was built in Shenzhen during the "8th Five-Year Plan". China's incinerators follow the model of "waste-to-energy (WTE)", in which the captured heat is converted to electricity for generating power supply. However, the operation of incineration plants has encountered limitations due to the high emissions of dioxin and the difficulty of disposing of incineration residue, which impact the environment and public health. To deal with the problem, China and the EU have used circulating fluidized bed combustion technology. The incineration of sewage sludge generates fly ash and slag that can be used for heavy metal removal from wastewater [22-25].

Figure 5 shows the waste collection system in China's cities [26]. The MSW is disposed of on the same day through closed collection and transportation. In urban areas, waste is collected by community's resident committees, property management companies, and waste cleaning companies, and then transferred to a local storage center [27]. 


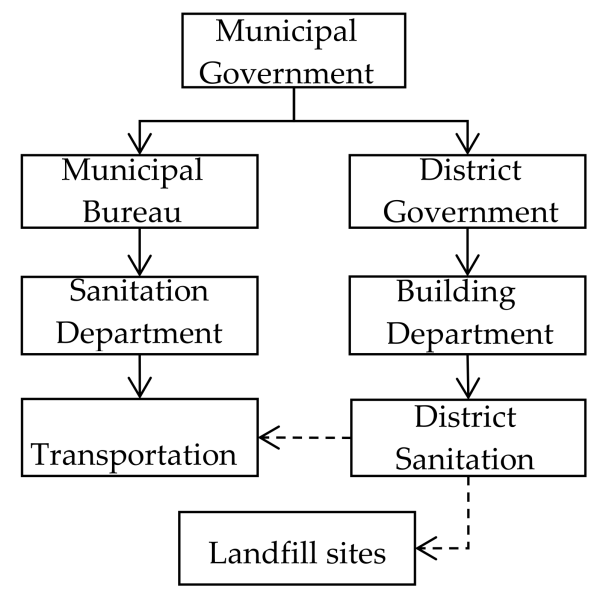

Figure 5. Collection system of MSW in China [20].

Incineration is a primary treatment for hazardous waste and industrial waste in China. In 2020, almost $35 \%$ of the total MSW was disposed of by incineration, with $61 \%$ sent to landfill and only $4.4 \%$ recycled [28]. The low recycling rate was attributed to the absence of a secondary materials market and due to no formal initiatives for recycling in place. In China, recycling systems are affected by the import of low-cost secondary materials from high-income countries that export their materials to avoid using their limited landfill capacity [29].

China has a long way to go with respect to waste separation, collection, recycling, reuse, end-disposal technology and the building of a management system, as compared to developed countries. The end of treatment for MSW leads to a huge waste of potential materials, increases the consumption of resources, and brings negative impacts on the environment. If MSW is well managed, it results in a large resource pool for electricity production and steam for heating [30].

\section{Evolution of MSW Management in China}

China has undergone an enormous economic development since 1978 following the implementation of its open door policy. Figure 6 illustrates the different stages of evolution in China's roadmap. To project to the future, China focuses on developing a CE-based waste management. However, the country's rapid economic development presents challenges related to environmental protection [31].

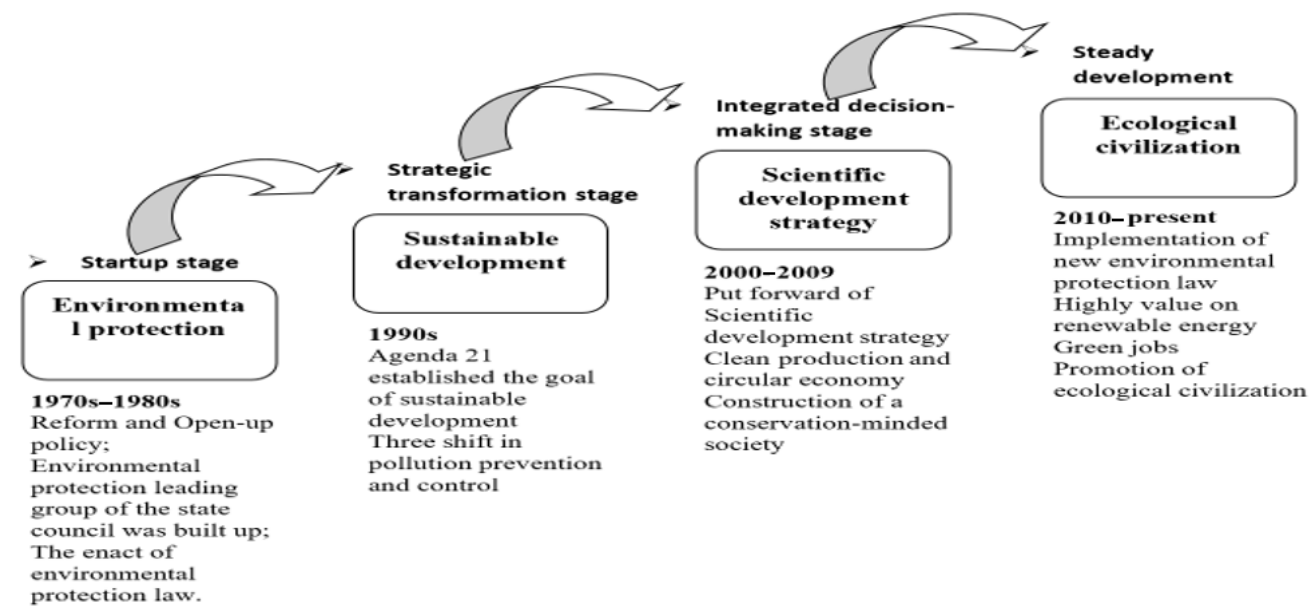

Figure 6. Evolution of China's economy development stage [21]. 


\subsection{Stage of Reform and Opening-Up}

Since the implementation of the reform and the opening-up policy, China's per capita GDP growth has been over $8 \%$ per year. The reform of the Chinese economy rests on the development of a market economy, which allowed China to catch up with the rest of the world. As Deng Xiaoping, the architect of China's open door policy, made it clear in 1978, China's prospects for economic development depended on the maintenance of a peaceful environment to support its economic growth. China's ability to pursue its economic reform since 1978 has been attributed to a relevant policy framework on economic development. Reform and the open door policy were among the first regulations, which paid attention to driving economic development. This not only efficiently boosted China's economy, but also affirmed the country's position in the global landscape [32].

At the same time, the scale of urbanization increased from $17.9 \%$ in 1978 to $51.3 \%$ in 2011, putting pressure on urban areas [33]. During this period, the amount of MSW has risen sharply with an annual growth rate that exceeds $10 \%$. The complex environment has made the open door policy become difficult to continue implementing. With environment degradation, this increases the responsibilities and obligations toward environmental protection. Therefore, in 1989, China issued the first law on environmental protection to mi-tigate the negative effects of economic development. Subsequently, China published its Solid Waste Pollution Prevention Law in 1995 [34].

\subsection{Stage of Agenda 21st}

The conflict between the environment and people potentially damaged China's economic development in the long term. To comply with the 21st Century Agenda of the United Nations (UN), the State Council of China promulgated a Five-Year national plan aimed at sustainable development in 1996. Due to rapid development and environmental damage, efforts have been made to bring the increasing environmental pollution and deterioration of the environment under control. Therefore, the State Council considered that a complete environmental management or related law system should be established in line with the existing laws [35].

In 1992, China developed a national 21st Century Agenda with respect to population and the environment [36]. The State Council was engaged in the formulation of the 21st Century Agenda. The core concept of the 21st Century Agenda is sustainable development, which means that the current system has to meet the demand of the present gene-ration without limiting the demands of future generations [37].

For this purpose, China collaborates with stakeholders to foster innovation to tackle the implications of MSW. For example, sustainable development sets a goal to reduce waste to $30 \%$ by 2030 by: strengthening the standardization of waste material recovery and recycling; establishing an integrated MSWM system of environmental laws, policies, and standards; providing technical support for waste reduction, recycling, and cleaner production; and mitigating the contamination caused by the waste. The 21st century Agenda concerns the protection of the environment, including the conservation and sustainable use of natural resources [38].

In 2005, the revised law on solid waste introduced the concept of the 3R's (reduce, recycle, and reuse) for waste management. In June 2008, China imposed a ban on the production, sale, and use of plastic bags [39]. This regulation prohibited any stores, shops, or supermarkets from giving free plastic bags to consumers. However, to date, those that implemented the 3R's movements have not been able to alleviate the pressure on landfills [40].

During this period, China carried out a series of initiatives to tackle the issues with solid waste, aiming to develop a low-carbon CE. Based on the "Law on Prevention and Control of Environmental Pollution caused by Solid Waste of PRC", the municipal government reduced the total amount of MSW by improving the recycling rate, preserving resources, and dismantling discarded electronic appliances monthly [41]. 
From 1990 to today, China enacted laws and regulations relating to environmental protection and solid waste management (Table 1). However, the system has limitations. With changes in legislation, environmental resource laws do not meet the requirements of sustainable development. The laws and regulations were enacted during the 1980s and have not been adapted to the economic system. The principles of a solid waste management system lack flexibility. During this period, problems such as inadequate disposal capacity of solid waste and poor management occurred.

Table 1. Development of solid waste treatment planning.

\begin{tabular}{ccc}
\hline Strategic Planning & Specific Policy & Main Content \\
\hline $\begin{array}{c}\text { Pollution prevention } \\
\text { and control planning }\end{array}$ & $\begin{array}{c}\text { The "12th Five-Year" plan of } \\
\text { national environmental } \\
\text { protection }\end{array}$ & $\begin{array}{c}\text { Strengthen environmental protection; mitigate environmental risks; } \\
\text { curb high incidence of environmental pollution events. }\end{array}$ \\
\hline $\begin{array}{c}\text { Pollution prevention } \\
\text { and control planning }\end{array}$ & $\begin{array}{c}\text { The "12th Five-Year" plan of } \\
\text { hazardous waste pollution } \\
\text { prevention planning }\end{array}$ & $\begin{array}{c}\text { By 2015, the nationally generated units of hazardous waste and } \\
\text { business units for the standardized management of hazardous wastes } \\
\text { qualified spot-check rate above 90\% and 95\%, respectively; waste } \\
\text { utilization industry value is expected to exceed CNY 200 billion. }\end{array}$ \\
\hline $\begin{array}{c}\text { Infrastructure } \\
\text { planning }\end{array}$ & $\begin{array}{c}\text { The "12th Five-Year" plan of } \\
\text { national urban living garbage } \\
\text { disposal facilities construction } \\
\text { plan }\end{array}$ & $\begin{array}{c}\text { (1) During the "twelfth five-year" period, the urban living garbage } \\
\text { disposal facilities construction will increase with a total investment of } \\
\text { about CNY 263.6 billion, which is 3.05 times the investment compared } \\
\text { to the period of the "11th five-year plan". }\end{array}$ \\
$\begin{array}{c}\text { Comprehensive } \\
\text { utilization of resources } \\
\text { and scientific and } \\
\text { technological }\end{array}$ & $\begin{array}{c}\text { The "12th Five-Year" plan of } \\
\text { bulky industrial solid waste } \\
\text { comprehensive utilization }\end{array}$ & $\begin{array}{c}\text { By 2015, the amount of national bulky industrial solid waste } \\
\text { comprehensive utilization reached 1.6 billion tons; the comprehensive } \\
\text { utilization rate reached 50\%; the annual output value reached CNY 500 } \\
\text { billion; during the period of "12th Five-Year" national plan, large } \\
\text { industrial solid waste comprehensive utilization reached 7 billion tons. }\end{array}$ \\
\hline
\end{tabular}

\subsection{Stage of Strategy}

When leaders change, the priority also changes [42]. When President Xi Jinping took up his presidency, a strategic road map was outlined under the concept of "One Belt, One Road". If carried out, it would lead China to the next level of development. This "One Belt, One Road" strategy is designed to meet national interests, including creating a CE.

The world is moving towards the direction of a $\mathrm{CE}$, which aims to reduce environmental risks and material scarcity for sustainability [43]. For this reason, China has taken a proactive approach when balancing economic development and environmental protection. China's transition to a CE has implications both domestic and worldwide. The go-vernment's strategy in transitioning to a $\mathrm{CE}$ provides jobs and saves resources. Based on the demand for economic transformation, a new road map for waste management needs to include digitalization. Under the current economic climate, which relies on fossil fuels for economic development, digitalization in waste management offers resource circularity to address material scarcity [44].

In China, several companies offer integrated system solutions combining software and hardware to enable garbage collection service providers to use highly efficient data services. This solution slashes costs and improves efficiency based on the internet of things (IoT) in waste management by gathering data about garbage collection from various industries and analyzing them using artificial intelligence (AI) algorithms to improve urban services. For this purpose, an integrated circuit is attached to trash bins to locate their place and alert data centers when the trash reaches its predetermined point [45].

\section{Roadmap of MSWM in China}

This section provides a framework of the waste sector and waste hierarchy. The future direction explains how it fits into the process of achieving sustainable development and how to cope with the challenge of resource scarcity at national and regional levels. 


\subsection{Greening the Waste Sector Framework}

Figure 7 presents a framework for an integrated resource management system in China. This framework relies on the concept of zero waste, which explains that everything we consume has two side effects: the consumption of natural resources for producing it, and the increase of waste when it becomes useless [46].

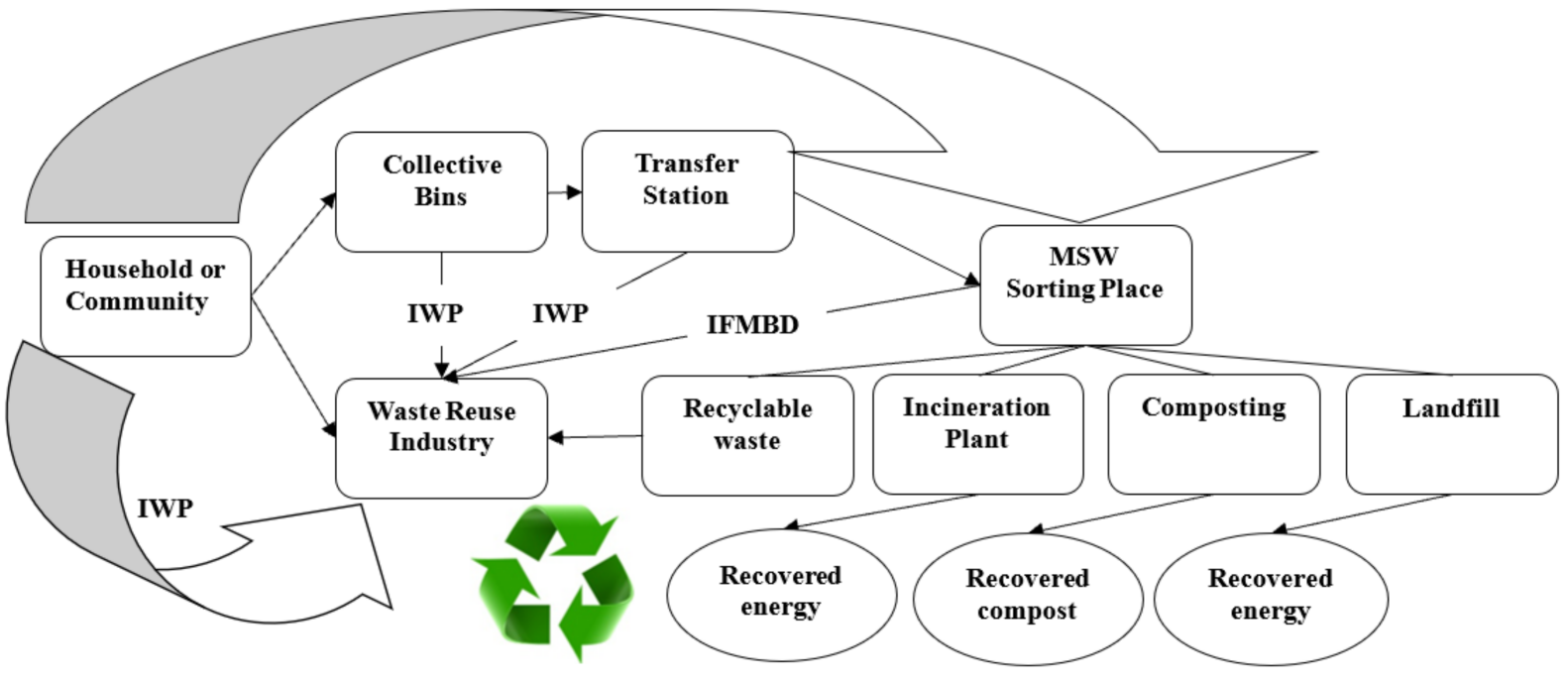

Figure 7. Framework for greening the waste sector.

Greening the waste sector relies on all stakeholders' involvement during the provision of the MSWM service. It involves a complex mixture of different department responsibilities and technologies. This approach can make use of the new technologies to preserve the stability of the ecosystem and improve the employment rate, while protecting the environment. All the aspects, from the point of generation to ultimate disposal, are taken into consideration during the digitalization of waste recycling [47]. A sound MSWM can reduce the emission of GHG through recycling and reusing [48].

Overall, the primary objective is to prevent and reduce food waste at source. So if we consume less and recycle more, then the waste amount decreases. Waste generators are responsible for turning food waste into renewable energy through composting and anaerobic digestion, while non-separated food waste is disposed of at landfills $[49,50]$.

\subsection{Waste Hierarchy}

An integrated MSWM system is based on the hierarchy of waste management (Figure 8), which combines the concept of 'reduce, reuse, recycle' (3Rs). The most preferred pillar is the prevention of waste, with the aim of encouraging people to reduce waste generation and to separate the recyclables from non-recyclables at source. Waste charging is encouraged for waste reduction/prevention. People pay less for the system if less is used. In developed countries, people are aware of their consumption levels. As a result, waste generation places them ahead of the developing world, who struggle with changing their systems.

The next priority is waste reuse and the recycling of recyclable materials [51]. In order to achieve high recovery efficiency in sorting and collection, a separating system must be established. Waste minimization, reuse, and recycling are dependent on waste separation at source. The Chinese government needs to open a new market for recycling materials. The recyclables generated from each waste sector are returned to the consumption cycle after reuse or recycling, promoting a $\mathrm{CE}$ nationwide. Economically, waste prevention, reduction, and reuse require less investment, while generating a higher return of investment. This enables China's cities to harness multiple climate co-benefits such as income generation and energy security. This requires a convergence of urban policies for mitigation and adaptation with techno-financial support for climate-sensitive development projects. 


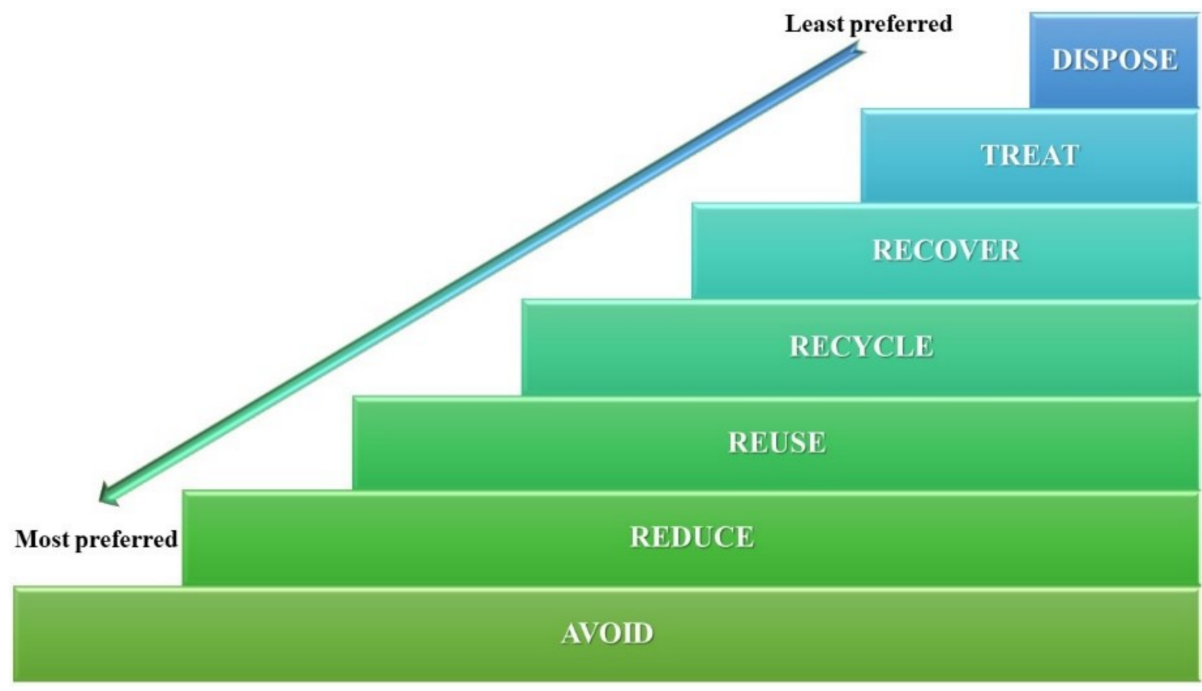

Figure 8. Waste management hierarchy [41].

After waste prevention, reuse, and recycling, residential waste must be disposed of properly through incineration, landfill, or waste-to-energy (WTE) technology. Any remaining materials are disposed of at landfills. Landfill provides space for residuals generated from incineration and composting [52]. When encountering increasing MSW and a shortage of land supply, other technologies, such as composting, anaerobic digestion, and WTE, can be developed to match the existing waste stream [53].

\section{Opportunities for Greening the Waste Sector}

6.1. Promising Market Prospects for Entrepreneurs in the Waste Sector

Greening the waste sector needs a transformation from a 'business-as-usual' approach, such as open dumping, to an economic method, which generates a direct benefit. Although the waste industry in China is still at an early stage of development, it has promising prospects [54].

During the period of the "12th Five-Year" plan, governments enacted a series of new measures in solid waste management (Table 1). During the period of the "11th Five-Year", the investment in environmental protection and waste management was USD 2160 billion and USD 210 billion, respectively, while at the end of the "12th Five-Year", the investment reached up to USD 3400 billion and USD 800 billion [55] (Figure 9).

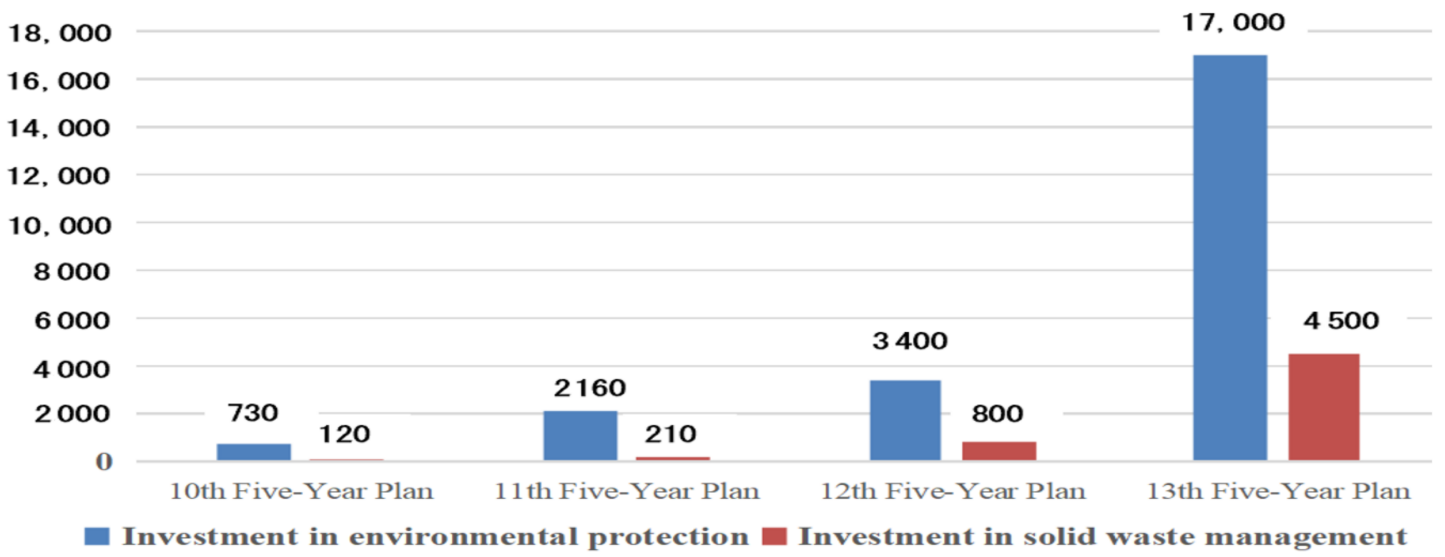

Figure 9. National policy of investment in environmental protection and waste management [45].

Greening the waste sector has benefits for the local government and MSWM companies, with incentives such as tax relief, environmental improvement funds, and tipping fees. 
Table 2 illustrates examples of market-based instruments in MSWM. The waste treatment companies benefit from the tipping fee for the waste collection from each household [56].

Table 2. Market-based instruments in MSWM.

\begin{tabular}{lll}
\hline Policy Option & Example & Description \\
\hline Waste taxes & $\begin{array}{l}\text { Tax credits; tax rebates; } \\
\text { tax relief; landfill tax }\end{array}$ & $\begin{array}{l}\text { Allowances on property taxes, customs duties, or } \\
\text { sales taxes to motivate investment in waste } \\
\text { management improvements }\end{array}$ \\
\hline Charge reduction & Tickets for littering & $\begin{array}{l}\text { Based on proof of recycling or reuse in reducing } \\
\text { wastes or requiring collection or disposal }\end{array}$ \\
\hline Deposit refund & Beverage containers & Refund given upon product return for reuse \\
\hline Eco-labeling & $\begin{array}{l}\text { Reusable shopping bags; } \\
\text { eco-labeled detergents }\end{array}$ & $\begin{array}{l}\text { Notes product's recyclable content and whether } \\
\text { product is recyclable }\end{array}$ \\
\hline
\end{tabular}

\subsection{Modern Technologies and Mature Law Promote Waste Sector Development}

Table 3 presents an overview of solid waste legislative regulations in China. Since the enactment of reform, environmental issues became worse because of industrialization. Up to now, the government has published environmental protection policies and regulations to cope with the environmental issues. The first laws about environmental protection and waste management were enacted in 1989 and 1996, respectively [57]. The major legislation in China for solid waste management are the Waste Disposal Act and Resource Recycling Act. The latter aims to conserve natural resources, reduce waste generation, and advocate for recycling, including the reuse of all materials.

Table 3. Summary of National Laws and Regulations on MSW in China [57].

\begin{tabular}{|c|c|c|c|}
\hline Laws and Regulations & Brief Description & Issuer & Effective Time \\
\hline $\begin{array}{l}\text { Law of Environmental Protection } \\
\text { of PRC }\end{array}$ & $\begin{array}{c}\text { To protect and improve environmental } \\
\text { quality; prevent pollution. }\end{array}$ & $\begin{array}{l}\text { The Standing Committee } \\
\text { of the National People's } \\
\text { Congress }\end{array}$ & $\begin{array}{l}26 \text { December } 1989 \\
\text { (24 April 2014) }\end{array}$ \\
\hline $\begin{array}{c}\text { Law on Prevention and Control of } \\
\text { Environmental Pollution Caused } \\
\text { by } \\
\text { Solid Waste of PRC }\end{array}$ & $\begin{array}{l}\text { First law to regulate the management of } \\
\text { MSW. }\end{array}$ & $\begin{array}{c}\text { The Standing Committee } \\
\text { of the National People's } \\
\text { Congress }\end{array}$ & $\begin{array}{l}1 \text { April } 1996 \\
\text { (24 April 2015) }\end{array}$ \\
\hline $\begin{array}{l}\text { Administration of } \\
\text { Comprehensive Utilization of } \\
\text { Renewable Resources }\end{array}$ & $\begin{array}{l}\text { For the conservation of natural resources, } \\
\text { reducing waste generation and increasing } \\
\text { recycling and sustainable use of } \\
\text { materials. }\end{array}$ & $\begin{array}{l}\text { Ministry of Commerce } \\
\text { of the People's Republic } \\
\text { of China }\end{array}$ & 3 July 2002 \\
\hline $\begin{array}{l}\text { Law for Promotion of Cleaner } \\
\text { Production of PRC }\end{array}$ & $\begin{array}{l}\text { At each step of production, the } \\
\text { manufacturers should take } \\
\text { measurements to reduce pollution. }\end{array}$ & $\begin{array}{l}\text { The Standing Committee } \\
\text { of the National People's } \\
\text { Congress }\end{array}$ & 1 January 2003 \\
\hline $\begin{array}{l}\text { Law for Environment Impact } \\
\text { Assessment of PRC }\end{array}$ & $\begin{array}{l}\text { Emphasize the importance of preventing } \\
\text { environmental pollution from source; any } \\
\text { new construction must obtain permission } \\
\text { to build. }\end{array}$ & $\begin{array}{l}\text { The Standing Committee } \\
\text { of the National People's } \\
\text { Congress }\end{array}$ & 1 September 2003 \\
\hline $\begin{array}{l}\text { Regulations on Municipal } \\
\text { Residential Solid Waste }\end{array}$ & $\begin{array}{l}\text { Management of collecting, transferring, } \\
\text { and treating residential waste. }\end{array}$ & $\begin{array}{l}\text { The Ministry of } \\
\text { Construction of PRC }\end{array}$ & 1 September 1993 \\
\hline $\begin{array}{l}\text { Technical Policies on the Disposal } \\
\text { of Domestic Waste and the } \\
\text { Prevention of Pollution }\end{array}$ & $\begin{array}{l}\text { Guidance and standards for the } \\
\text { technologies applied in MSW treatment. }\end{array}$ & $\begin{array}{l}\text { The Ministry of } \\
\text { Construction of PRC }\end{array}$ & June 2000 \\
\hline
\end{tabular}




\section{Multiple Benefits of Greening the Waste Sector}

The waste sector could contribute to multiple benefits for China in terms of social, economic, political, and environment factors. The sector gives due consideration to a stream of waste that has significant benefits for volume, the economy, society, and the environment and the related implications and opportunities for the future of China (Figure 10).

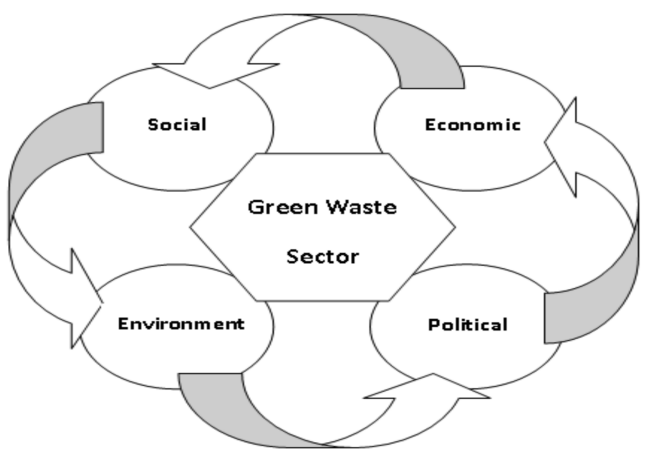

Figure 10. Implications of greening the waste sector.

Based on the CE paradigm, the waste sector can combine all departments, enabling them to become involved in the collection, transportation, and final disposal of MSW. The renewable energy, electricity, and compost generated from the reuse of solid waste reduces the demand for resources and minimizes GHG release indirectly [41-43]. Due to resource scarcity, the benefits of energy generation from waste are an incentive to develop the waste sector.

Greening the waste sector creates new job opportunities directly and indirectly, which also adds value to laborers. Scavenging is informal waste collection through door-todoor bell-ringing collection due to the lack of adequate MSW collection and separation systems $[44,45]$. Scavenging is an opportunity for the poor to earn their living. They not only play an important role in the food basket of poor urban households, but also promote job creation. An integrated MSWM can alleviate poverty and lower the cost of raw materials, while protecting the environment through reuse and recycling [58].

The waste sector benefits economic development by promoting the development of waste-to-energy (WTE) systems across industry. The WTE approach is considered to be a part of the waste management system [49]. WTE not only contributes to reducing GHG emissions (Figure 11), but also materializes the benefits from energy recovery [50]. The annual benefits from the sales of electricity, thermal power, and recyclable waste have driven the development of the WTE industry. In China, income from the WTE business is electricity sales, which ranges from 70 to $85 \%$ of the total income and tipping fees [50].

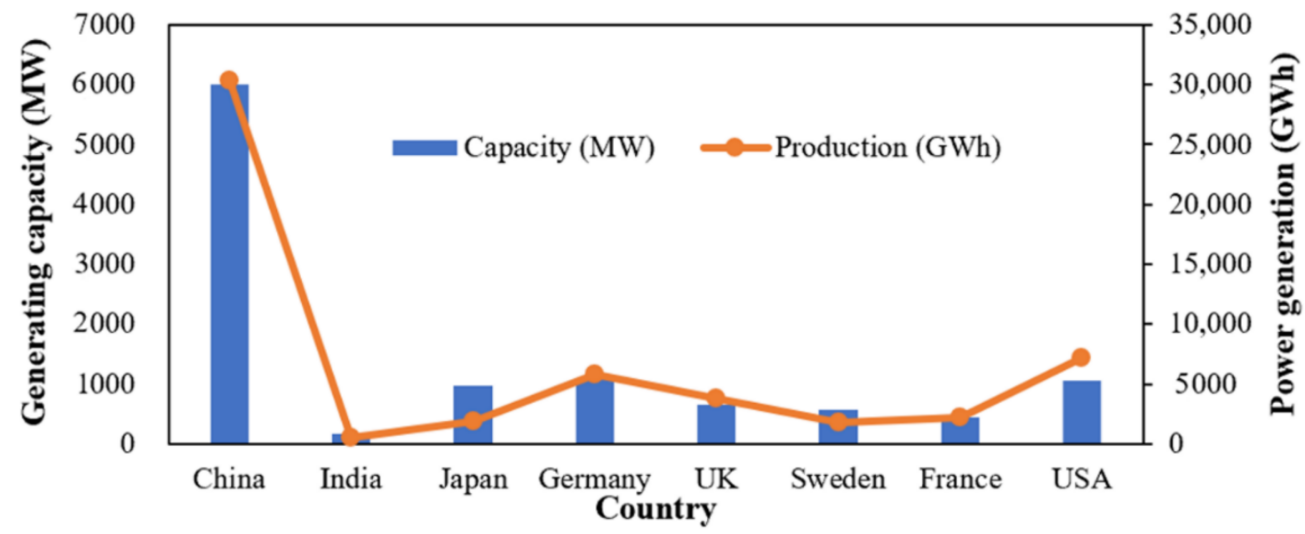

Figure 11. Electricity generation for waste sector in different countries [53]. 


\section{The Way forward for Digitalization to Promote a CE in the Waste Sector}

The recycling sector has the potential to seize the opportunities of a CE through di-gitalization. Although landfill is a main tool for waste disposal, the future lies in digita-lizing waste recycling in the market. Digitalization, defined as "the use of digital techno-logies to change a business model", provides critical solutions for strengthening waste management practices to mitigate its impacts on the environment by generating real-time data about the location, condition, and availability of non-organic waste, increasing traceability and improving ease of access to products and services. This creates the possibility of interoperable automation in waste management for non-organic waste. This enables people to rely on digitalization to streamline the physically intensive work [51]. It takes at least two years to introduce digitalization in an enterprise from idea formation to its implementation.

The use of digital technologies for efficient waste management is feasible and enables the development of 'Pay-As-You-Throw' systems, 'Know-As-You-Throw' (KAYT) schemes, and the use of 'Radio Frequency Identification' (RFID), which monitors waste fractions at source. If waste collection service companies adopted digital solutions, such as RFID or artificial intelligence (AI), the time required for waste collection could be reduced by $35 \%$. This competitiveness enables the companies involved to efficiently deploy driverless trucks to the designated points of waste collection citywide.

Embracing digitalization in the waste industry will keep the recycling system in place and businesses alive amidst the current pandemic by providing the strategic move essential to make leapfrogging progress. This help the waste industry to shift towards sustainable solutions with the traceability of waste flows. As a result, we could avoid the GHGs that may be emitted from manufacturing virgin resources, minimizing $\mathrm{CH}_{4}$ emissions [52].

Digitalization is critical to help MSWM achieve its goals by boosting the transformation towards a sustainable $\mathrm{CE}$ by narrowing the material loops with increased resource efficiency. By fostering technological innovation in products and processes, digitalization promotes efficient waste minimization and longer life for products, and reduces transaction costs. Without digitalization, a CE will form slowly, with few attractive circular business models and less impact on global climate goals. Without a coherent and inclusive global digitalization effort, a climate goal cannot be attained in a timely manner [59].

Digital technologies could be integrated in local waste management systems, after being improved to secure an efficient market. Digitalization not only addresses the impacts of global change caused by non-organic waste, but also establishes a post-COVID-19 world with the characteristics of being resilient, sustainable, safe, and equitable by mi-tigating the economic shocks due to the pandemic [60].

\section{Concluding Remarks}

The article has reviewed and analyzed the transformation of MSMW in China over the past four decades. The increasing environmental awareness, stricter legislation, urban concentration, and population growth have contributed to the evolution of MSWM in China. As its cities grow rapidly and strive to achieve world-class status, investment in sustainable urban waste management systems towards a CE model is necessary to create environmentally friendly, livable, and sustainable cities nationwide.

Investment in smart city initiatives can enhance planning, preparation ability, and capacity to respond to the global pandemics that require timely and integrated actions. The availability and proper application of such technologies could contribute to waste digitalization in the era of 4IR.

It is evident from the literature survey that digitalization is a driving force for China, helping it move towards low-carbon development strategies in the framework of CE. Harnessing digital solutions for the waste recycling industry is a viable solution to strengthen a circular, resource-efficient, and low-carbon economy. In the era of Industry 4.0, digital solutions have the ability to improve waste recycling practices. With digitalization, a proper waste management system is mandatory to protect the environment and public health. 
Through digitalization, the waste sector could contribute to the country's CE in the move towards sustainable development. Digitalization not only strengthens MSWM in China, but it also maximizes the utilization efficiency through waste recycling.

Author Contributions: Conceptualization, X.L.; Methodology, E.O.; Validation, T.D.K.; formal analysis, X.L.; Investigation, H.G.; Resources, H.G.; Data curation, E.O.; Writing-original draft preparation, T.A.K.; Writing-review and editing, T.A.K.; Supervision, R.A.; Project administration, M.H.D.O.; Funding acquisition, M.H.D.O. All authors have read and agreed to the published version of the manuscript.

Funding: This work received a Research Grant No. Q.J130000.21A6.00P14 from Universiti Teknologi Malaysia (UTM).

Conflicts of Interest: The authors declare no conflict of interest. The funders had no role in the design of the study; in the collection, analyses, or interpretation of data; in the writing of the manuscript, or in the decision to publish the results.

\section{References}

1. National Bureau of Statistics of China (NBS). The National Economic and Social Development Statistical Bulletin in 2014. Available online: http:/ / www.stats.gov.cn/tjsj/zxfb /201502/t20150226_685799.html (accessed on 1 January 2022).

2. Gallardo, A.; Carlos, M.; Peris, M.; Colomer, FJ. Methodology to design a municipal solid waste generation and composition map: A case study. Waste Manag. 2014, 34, 1920-1931. [CrossRef]

3. Skrzypkowski, K.; Korzeniowski, W.; Poborska-Młynarska, K. Binding capability of ashes and dusts from municipal solid waste incineration with salt brine and geotechnical parameters of the cemented samples. Arch. Min. Sci. 2018, 63, 903-918. [CrossRef]

4. Korzeniowski, W.; Skrzypkowski, K.; Poborska-Młynarska, K. The idea of the recovery of municipal solid waste incineration (MSWI) residues in Kłodawa salt mine S.A. by filling the excavations with self-solidifying mixtures. Arch. Min. Sci. 2018, 63, 553-565. [CrossRef]

5. Yazdani, M.; Kabirifar, K.; Frimpong, B.E.; Shariati, M.; Mirmozaffari, M.; Boskabadi, A. Improving construction and demolition waste collection service in an urban area using a simheuristic approach: A case study in Sydney, Australia. J. Clean. Prod. 2021, 280, 124138. [CrossRef]

6. Kabirifar, K.; Mojhatedi, M.; Wang, C.; Tam, V.W.Y. Construction and demolition waste management contributing factors coupled with reduce, reuse, and recycle strategies for effective waste management: A review. J. Clean. Prod. 2020, 263, 121265. [CrossRef]

7. Palanivel, T.M.; Sulaiman, H. Generation and composition of municipal solid waste (MSW) in Muscat, Sultanate of Oman. APCBEE Procedia 2014, 10, 96-102. [CrossRef]

8. Zhao, Y.; Christensen, T.H.; Lu, W.; Wu, H.; Wang, H. Environmental impact assessment of solid waste management in Beijing City, China. Waste Manag. 2011, 31, 793-799. [CrossRef]

9. Khan, D.; Kumar, A.; Samadder, S.R. Impact of socioeconomic status on municipal solid waste generation rate. Waste Manag. 2016, 49, 15-25. [CrossRef]

10. Fu, Z.; Zhang, S.; Li, X.; Shao, J.; Wang, K.; Chen, H. MSW oxy-enriched incineration technology applied in China: Combustion temperature, flue gas loss and economic considerations. Waste Manag. 2015, 38, 149-156. [CrossRef]

11. Kurniawan, T.A.; Lo, W.H.; Sillanpää, M.E. Treatment of contaminated water laden with 4-chlorophenol using coconut shell waste-based activated carbon modified with chemical agents. Sep. Sci. Technol. 2011, 46, 460-472. [CrossRef]

12. Zhu, M.; Kurniawan, T.A.; Yanping, Y.; Dzarfan Othman, M.H.; Avtar, R.; Fu, D.; Hwang, G.H. Fabrication, characterization, and application of ternary magnetic recyclable $\mathrm{Bi}_{2} \mathrm{WO}_{6} / \mathrm{BiOI}_{\mathrm{F}} \mathrm{Fe}_{3} \mathrm{O}_{4}$ composite for photodegradation of tetracycline in aqueous solutions. J. Environ. Manag. 2020, 270, 110839. [CrossRef]

13. Premakumara, D.G.J.; Canete, A.L.M.L.; Nagaishi, M.; Kurniawan, T.A. Policy implementation of the Republic Act (RA) No. 9003 in the Philippines on MSW management: A case study of Cebu City. Waste Manag. 2014, 34, 971-979. [CrossRef] [PubMed]

14. Guan, Y.; Ge, C.; Li, Z.; Nie, X.; Zhang, Z.; Luo, A. Metal contents and composting feasibility of rural waste from abandoned dumping site in Zhejiang, China. Energy Proc. 2011, 5, 1274-1278. [CrossRef]

15. Zhang, W.; Zhang, L.; Li, A. Anaerobic co-digestion of food waste with MSW incineration plant fresh leachate: Process performance and synergistic effects. Chem. Eng. J. 2015, 259, 795-805. [CrossRef]

16. Satya, A.; Harimawan, A.; Haryani, G.S.; Johir, M.A.H.; Vigneswaran, S.; Kurniawan, T.A.; Setiadi, T. Integrated treatment of submerged membrane and adsorption using dried Aphanothece sp for removal of cadmium from synthetic wastewater. J. Water Proc. Eng. 2021, 41, 102022. [CrossRef]

17. Xiao, L.; Lin, T.; Chen, S.; Zhang, G.; Ye, Z.; Yu, Z. Characterizing urban household waste generation and metabolism considering community stratification in an urbanizing area of China. PLoS ONE 2015, 10, e0145405. [CrossRef]

18. Fu, D.; Kurniawan, T.A.; Li, H.; Wang, H.; Wang, Y.; Li, Q. Co-oxidative removal of As(III) and tetracycline (TC) from aqueous solutions based on a heterogeneous Fenton's oxidation using Fe nanoparticles (Fe NP)-impregnated solid digestate. Environ. Pollut. 2021, 290, 118062. [CrossRef] 
19. Allegrini, E.; Vadenbo, C.; Boldrin, A.; Astrup, T.F. Life cycle assessment of resource recovery from municipal solid waste incineration bottom ash. J. Environ. Manag. 2015, 151, 132-143. [CrossRef] [PubMed]

20. Cheng, H.; Hu, Y. Curbing dioxin emissions from municipal solid waste incineration in China: Re-thinking about management policies and practices. Environ. Pollut. 2010, 158, 2809-2814. [CrossRef]

21. Zhou, H.; Meng, A.; Long, Y.; Li, Q.; Zhang, Y. A review of dioxin-related substances during municipal solid waste incineration. Waste Manag. 2015, 36, 106-118. [CrossRef]

22. Kurniawan, T.A.; Avtar, R.; Singh, D.; Xue, W.; Dzarfan Othman, M.H.; Hwang, G.H.; Iswanto, I.; Albadarin, A.B.; Kern, A.O. Reforming MSWM in Sukunan (Yogjakarta, Indonesia): A case-study of applying a zero-waste approach based on circular economy paradigm. J. Clean. Prod. 2020, 124775. [CrossRef]

23. Gao, P.Q. Management and integrated treatment planning of municipal domestic waste in Xiamen City. Environ. Sanit. Eng. 2007, 15,8 .

24. Kurniawan, T.A.; Oliveira, J.P.; Gamaralalage, P.J.D.; Nagaishi, M. City-to-city level cooperation for generating urban co-benefits: The case of technological cooperation in the waste sector between Surabaya (Indonesia) and Kitakyushu (Japan). J. Clean. Prod. 2013, 58, 43-50. [CrossRef]

25. Vilve, M.; Vilhunen, S.; Vepsäläinen, M.; Kurniawan, T.A.; Lehtonen, N.; Isomäki, H.; Sillanpää, M. Degradation of 1,2dichloroethane from contaminated water laden with ion-exchange resin using Fenton's oxidation. Environ. Sci. Pollut. Res. 2010, 17, 875-884. [CrossRef] [PubMed]

26. Lin, Y.; Kurniawan, T.A.; Yi, Z.; Albadarin, A.; Walker, G. Enhanced photocatalytic degradation of acetaminophen from wastewater using $\mathrm{WO}_{3} / \mathrm{TiO}_{2} / \mathrm{SiO}_{2}$ composite under UV-VIS irradiation. J. Mol. Liq. 2017, 243, 761-770. [CrossRef]

27. Kalak, T.; Tachibna, Y. Removal of lithium and uranium from seawater using fly ash and slag generated in the CFBC technology. RSC Adv. 2021, 11, 21964-21978. [CrossRef]

28. Kalak, T.; Cierpiszewski, R.; Ulewicz, M. High efficiency of the removal process of $\mathrm{Pb}(\mathrm{II})$ and $\mathrm{Cu}(\mathrm{II})$ ions with the use of fly ash from incineration of sunflower and wood waste using the CFBC technology. Energies 2021, 14, 1771. [CrossRef]

29. Kurniawan, T.A.; Singh, D.; Avtar, R.; Dzarfan Othman, M.H.; Hwang, G.H.; Albadarin, A.B.; Rezakazemi, M.; Setiadi, T.; Shirazian, S. Resource recovery from landfill leachate: An experimental investigation and perspectives. Chemosphere 2021, 274, 129986. [CrossRef] [PubMed]

30. Kurniawan, T.A.; Singh, D.; Xue, W.; Avtar, R.; Othman, M.H.D.; Hwang, G.H.; Setiadi, T.; Albadarin, A.B.; Shirazian, S. Resource recovery toward sustainability through nutrient removal from landfill leachate. J. Environ. Manag. 2021, 287, 112265. [CrossRef]

31. Kurniawan, T.A.; Lo, W.H.; Repo, E.; Sillanpää, M.E. Removal of 4-chlorophenol from contaminated water using coconut shell waste pretreated with chemical agents. J. Chem. Technol. Biotechnol. 2010, 85, 1616-1627. [CrossRef]

32. Kurniawan, T.A.; Lo, W.; Singh, D.; Othman, M.H.D.; Avtar, R.; Hwang, G.H.; Albadarin, A.B.; Kern, A.O.; Shirazian, S. A societal transition of MSW management in Xiamen (China) toward a circular economy through integrated waste recycling and technological digitization. Environ. Pollut. 2021, 277, 116741. [CrossRef]

33. Zhou, C.; Gong, Z.; Hu, J.; Cao, A.; Liang, H. A cost-benefit analysis of landfill mining and material recycling in China. Waste Manag. 2015, 35, 191-198. [CrossRef] [PubMed]

34. Marsal-Llacuna, M.-L.; Segal, M.E. The Intelligenter method (I) for making "smarter" city projects and plans. Cities 2016, 55, 127-138. [CrossRef]

35. Anagnostopoulos, T.; Kolomvatsos, K.; Anagnostopoulos, C.; Zaslavsky, A.; Hadjiefthymiades, S. Assessing dynamic models for high priority waste collection in smart cities. J. Syst. Softw. 2015, 110, 178-192. [CrossRef]

36. Babel, S.; Kurniawan, T.A. Low-cost adsorbents for heavy metal uptake from contaminated water: A review. J. Hazard. Mater. 2003, B97, 219-243. [CrossRef]

37. Li, Y.; Zhao, X.; Li, Y.; Li, X. Waste incineration industry and development policies in China. Waste Manag. 2015, 46, $234-241$. [CrossRef]

38. Zhao, X.; Jiang, G.; Li, A.; Li, Y. Technology, cost, a performance of waste-to-energy incineration industry in China. Renew. Sustain. Energy Rev. 2016, 55, 115-130. [CrossRef]

39. Li, L.; Hao, T.; Chi, T. Evaluation on China's forestry resources efficiency based on big data. J. Clean. Prod. 2017, 142, 513-523. [CrossRef]

40. Kaivo-Oja, J.; Vehmas, J.; Luukkanen, J. Trend analysis of energy and climate policy environment: Comparative electricity production and consumption benchmark analyses of China, Euro area, European Union, and United States. Renew. Sustain. Energy Rev. 2016, 60, 464-474. [CrossRef]

41. Zheng, X.; Wang, C.; Cai, W.; Kummu, M.; Varis, O. The vulnerability of thermoelectric power generation to water scarcity in China: Current status and future scenarios for power planning and climate change. Appl. Energy 2016, 171, 444-455. [CrossRef]

42. Lund, J.W.; Boyd, T.L. Direct utilization of geothermal energy 2015 worldwide review. Geothermics 2016, 60, 66-93. [CrossRef]

43. Hepbasli, A.; Ozgener, L. Development of geothermal energy utilization in Turkey: A review. Renew. Sustain. Energy Rev. 2004, 8, 433-460. [CrossRef]

44. Aikins, K.A.; Choi, J.M. Current status of the performance of GSHP (ground source heat pump) units in the Republic of Korea. Energy 2012, 47, 77-82. [CrossRef]

45. Yang, J.; Zhang, W.; Zhang, Z. Impacts of urbanization on renewable energy consumption in China. J. Clean. Prod. 2016, 114, 443-451. [CrossRef] 
46. Zhu, M.; Kurniawan, T.A.; You, Y.; Othman, M.H.D.; Avtar, R. 2D Graphene oxide (GO) doped $p$ - $n$ type $\mathrm{BiOI} / \mathrm{Bi}_{2} \mathrm{WO} 6$ as a novel composite for photodegradation of bisphenol A (BPA) in aqueous solutions under UV vis irradiation. Mater. Sci. Eng. C 2020, 108, 110420. [CrossRef]

47. Lu, M.C.; Chen, Y.; Chiou, M.R.; Chen, M.; Fan, H.-J. Occurrence and treatment efficiency of pharmaceuticals in landfill leachates. Waste Manag. 2016, 55, 257-264. [CrossRef]

48. Saqib, N.; Bäckström, M. Chemical association and mobility of trace elements in 13 different fuel incineration bottom ashes. Fuel 2016, 172, 105-117. [CrossRef]

49. Fu, D.; Kurniawan, T.A.; Lan, L.; Yaqiong, L.; Avtar, R.; Othman, M.H.D. Arsenic removal from aqueous solution by FeS $2 . J$ Environ. Manag. 2021, 286, 112246. [CrossRef] [PubMed]

50. Liu, A.; Ren, F.; Lin, W.Y.; Wang, J.-Y. A review of municipal solid waste environmental standards with a focus on incinerator residues. Int. J. Sustain. Built Environ. 2015, 4, 165-188. [CrossRef]

51. Kurniawan, T.A.; Liang, X.; Singh, D.; Othman, M.H.D.; Goh, H.H.; Gikas, P.; Kern, A.O.; Kusworo, T.D.; Shoqeir, J.A. Harnessing landfill gas (LFG) for electricity: A strategy to mitigate greenhouse gas (GHG) emissions in Jakarta (Indonesia). J. Environ. Manag. 2022, 301, 113882. [CrossRef]

52. de Richter, R.K.; Ming, T.; Caillol, S.; Liu, W. Fighting global warming by GHG removal: Destroying CFCs and HCFCs in solar-wind power plant hybrids producing renewable energy with no-intermittency. Int. J. Greenh. Gas Control 2016, 49, 449-472. [CrossRef]

53. Bos, H.L.; Meesters, K.P.H.; Conijn, S.G.; Corré, W.J.; Patel, M.K. Comparing biobased products from oil crops versus sugar crops with regard to non-renewable energy use, GHG emissions and land use. Ind. Crops Prod. 2016, 84, 366-374. [CrossRef]

54. Fu, D.; Kurniawan, T.A.; Avtar, R.; Xu, P.; Othman, M.H.D. Recovering heavy metals from electroplating wastewater and their conversion into $\mathrm{Zn}_{2} \mathrm{Cr}$-layered double hydroxide ( $\mathrm{LDH}$ ) for pyrophosphate removal from industrial wastewater. Chemosphere 2021, 271, 129861. [CrossRef] [PubMed]

55. Simatele, D.; Etambakonga, C.L. Scavenging for solid waste in Kinshasa: A livelihood strategy for the urban poor in the Democratic Republic of Congo. Habitat Int. 2015, 49, 266-274. [CrossRef]

56. Wang, Y.; Geng, S.; Zhao, P.; Du, H.; He, Y.; Crittenden, J. Cost-benefit analysis of GHG emission reduction in waste to energy project of China under clean development mechanism. Resour. Conserv. Recycl. 2016, 109, 90-95. [CrossRef]

57. Jamasb, T.; Nepal, R. Issues and options in waste management: A social cost-benefit analysis of waste-to-energy in UK. Resour. Conserv. Recycl. 2010, 54, 1341-1352. [CrossRef]

58. Wang, Y.; Yan, Y.; Chen, G.; Zuo, J.; Du, H. Effective approaches to reduce greenhouse gas emissions from waste to energy process: A China study. Resour. Conserv. Recycl. 2015, 104, 103-108. [CrossRef]

59. Zhao, X.G.; Jiang, G.W.; Li, A.; Wang, L. Economic analysis of waste-to-energy industry in China. Waste Manag. 2016, 48, 604-618. [CrossRef]

60. Kurniawan, T.A.; Othman, M.H.D.; Singh, D.; Avtar, R.; Goh, H.H.; Setiadi, T.; Lo, W.H. Technological solutions for long-term management of partially used nuclear fuel: A critical review. Ann. Nucl. Energy 2022, 166, 108736. [CrossRef] 